\title{
A Invenção de Chacinas Escolares: das representações psi às rotas de fuga
}

\author{
Karyne Dias Coutinho' \\ Alexander de Freitas' \\ 'Universidade Federal do Rio Grande do Norte (UFRN), Natal/RN - Brasil
}

RESUMO - A Invenção de Chacinas Escolares: das representações psi às rotas de fuga. A partir da ideia deleuziana de que o cinema possibilita a ativação e a potencialização do pensamento, este estudo se movimenta entre as representações de chacinas escolares inventadas pelo filme Elefante (Gus Van Sant, EUA, 2003) e pela revista Veja (ed. 2.212, n. 15, 13 abr. 2011). Ao evidenciar as diferenças dos modos como Elefante e Veja inventam as respectivas chacinas de que tratam, o estudo conclui que, por meio da multiplicidade como chave da representação, Elefante inaugura uma rota de fuga que permite outras possibilidades de pensar sobre chacinas escolares, impossível de ser traçada por meio das representações $p s i$ contidas nas reportagens de Veja.

Palavras-chave: Gilles Deleuze. Invenção. Representação. Chacina Escolar.

\begin{abstract}
The Invention of School Shootings: from psych representations to escape routes. From the Deleuzian idea that cinema allows the activation and potentiation of thought, this study moves between the representations of school shootings invented by the movie Elephant (Gus Van Sant, EUA, 2003) and the Brazilian magazine Veja (ed. 2.212, n. 15, Apr. 13 2011). By focusing on the differences in the ways Elephant and Veja invent their shootings, the study concludes that, through the multiplicity as key representation, Elephant opens an escape route that allows other possibilities of thinking about school shootings, impossible to be traced through the psi representations contained in the reports of Veja.

Keywords: Gilles Deleuze. Invention. Representation. School Shootings.
\end{abstract}

Educação \& Realidade, Porto Alegre, v. 39, n. 1, p. 303-323, jan./mar. 2014. 
A Invenção de Chacinas Escolares

A chacina escolar que ficou conhecida como massacre de Realengo e que aconteceu em 7 de abril de 2011, na Escola Municipal Tasso da Silveira - Realengo, Rio de Janeiro, Brasil - foi amplamente noticiada por diferentes tipos de mídia, como uma "tragédia que chocou o país" (Veja, 2011, p. 84). Sobre ela, foi produzida uma série de enunciados e representações, numa tentativa de encontrar causas capazes de explicar um fenômeno tão "cruel e aterrador" (Veja, 2011, p. 81) quanto esse.

O que propomos neste artigo é problematizar as representações que foram inventadas para: 1) o massacre de Columbine, pelo filme Elefante $^{1}$ (Gus Van Sant, EUA, 2003); 2) o massacre de Realengo, pelo conjunto de reportagens publicadas na edição especial da revista Veja (2011).

A escolha por usar o filme Elefante para compor essa problematização advém da ideia, cerne de nossas investigações atuais ${ }^{2}$, de que o cinema pode violentar/abalar o pensamento, de modo a possibilitar a ativação e a potencialização do ato de pensar (Deleuze, 1990). Isso significa que estamos fazendo um uso diferenciado do cinema na educação, cuja relação de modo geral acontece atribuindo-se ao cinema uma função didático-pedagógica com o objetivo de facilitar o ensinoaprendizagem de conceitos, ideias, movimentos artísticos, históricos e/ ou socioculturais. Escapando a essa função clichê e dominante, nossa aposta teórico-metodológica é a de que o cinema pode fazer devir o pensamento, criando condições de possibilidade para o impensado e para o impensável, a partir do poder que tem de causar choques nos nossos modos usuais de pensar.

Se usamos no título e no decorrer deste texto a ideia de invenção das chacinas escolares - isto é, o fato de que as chacinas escolares são inventadas, fabricadas, criadas, produzidas, forjadas, através dos modos como são narradas -, é para marcar a perspectiva pós-estruturalista ${ }^{3}$ das lentes analíticas aqui utilizadas, a partir das contribuições, sobretudo, de Nietzsche, Foucault, Deleuze e Derrida.

Estudando a preferência de Nietzsche pelo termo invenção (do alemão Erfindung) em vez de origem (do alemão Ursprung), Foucault (2005) faz duas importantes considerações das quais nos valemos neste trabalho como orientação teórico-metodológica: 1) O termo invenção afasta e desnaturaliza qualquer a priori tomado como fundamento originário ou causa primeira - afasta-se, portanto, da ideia de uma suposta qualidade ou fundamento essencial e originário, anistórico, verdadeiro em si e autorreferente. Nesse sentido, qualquer representação é produto de delimitações arbitrárias e de uma escolha unilateral; 2) Se não há uma verdade originária e essencial, o termo invenção implica o entendimento de que são as relações de poder que fazem com que um conceito ou uma representação sejam tidos e reconhecidos como verdadeiros. Daí que o uso do termo invenção traz à tona a vontade de poder, de dominação e de assujeitamento que está no cerne de qualquer representação ou verdade dominante/instituída, colocando as lutas, a dissensão, 
as disputas e a vontade de submissão como movedores da invenção de uma representação.

Esse duplo movimento instaurado pelo conceito de invenção é muito profícuo para as análises que pretendemos neste texto, porque tanto desnaturaliza a verdade dos discursos que inventam causas supostamente originárias e essenciais como a razão de ser das chacinas escolares, quanto põe a tônica das análises na problematização dos efeitos de poder, dominação e assujeitamento de determinados tipos de representação que são inventados para se narrar, perceber e pensar uma chacina escolar.

Movimentando-nos entre as representações de chacinas escolares inventadas pelo filme Elefante e pela revista Veja, perguntamos: que representações Elefante e Veja inventam de uma chacina escolar? Quais são os efeitos de poder dessas invenções? A quais ideias diferenciais, sobre o modo de representação das chacinas escolares, Elefante nos incita? Quais rotas de fuga das representações dominantes são possíveis?

Antes de irmos ao enfrentamento dessas questões, uma precaução metodológica se faz necessária: no caso do estudo aqui apresentado, tais questões são feitas acerca de representações de chacinas escolares inventadas por dois materiais empíricos distintos - cinema e reportagem jornalística -, o que não compromete o rigor da análise, na medida em que não é a natureza do material empírico que está em questão aqui, mas a ideia de que, independentemente do material, seja cinematográfico, seja jornalístico, suas representações são invenções, e o que nos interessa delas não são tanto os seus conteúdos em si quanto os efeitos que eles causam em nós, no sentido de podermos pensar não necessariamente sobre as representações inventadas pelo filme ou pela reportagem, mas entre elas ${ }^{4}$.

Essa ressalva é de fundamental importância para este estudo, na medida em que a ele importam os encontros possíveis entre representações distintas inventadas por domínios independentes um do outro. O conceito de encontro, na acepção deleuziana, potencializa a escolha metodológica que fazemos pelo entre:

Um encontro é talvez a mesma coisa que um devir ou núpcias. [...] Ele designa um efeito, um ziguezague, algo que passa ou que se passa entre dois como sob uma diferença de potencial: 'efeito Compton', 'efeito Kelvin'. Dizíamos a mesma coisa para os devires: não é termo que se torna outro, mas cada um encontra o outro, um único devir que não é comum aos dois, já que eles não têm nada a ver um com o outro, mas que está entre os dois, que tem sua própria direção, um bloco de devir, uma evolução a-paralela. É isso a dupla captura, a vespa e a orquídea: sequer algo que estaria em um, ou alguma coisa que estaria no outro, ainda que houvesse uma troca, uma mistura, mas alguma coisa que está entre os dois, fora dos dois, e que corre em outra direção (Deleuze; Parnet, 1998, p. 14-15).

Educação \& Realidade, Porto Alegre, v. 39, n. 1, p. 303-323, jan./mar. 2014

Disponível em: <http://www.ufrgs.br/edu_realidade> 
Esta acepção de encontro nos ajuda a justificar o trabalho com dois materiais distintos - cinematográfico e jornalístico -, uma vez que são dois domínios independentes, que necessariamente não se comunicam, ou melhor, que não precisam se comunicar, que não precisam um do outro para se dizer ou para se explicar: são dois domínios que se dizem por si. Ainda assim, e por isso mesmo, há devires possíveis: fazer passar entre, forjar encontros entre representações cinematográficas e jornalísticas é uma aposta metodológica que pretende driblar a interpretação, a identificação e o comentário, substituindo-os por uma tática rizomática que afirma o entre, entendido como cruzamentos, atravessamentos, intersecções - encontros - de representações cinematográficas e jornalísticas, umas desterritorializando as outras. Assim, a ideia não é pensar sobre as representações, mas entre elas, pensar por abertura a encontros entre as representações e com o de fora delas. Nesse sentido, tanto melhor se forem de domínios diferentes.

Ressalva feita, passemos à sequência do texto, organizado em três partes. A primeira parte aborda como o filme Elefante consegue escapar da busca de explicações e causas originárias e deterministas para o massacre de Columbine, por meio do jogo de paradoxos que coloca em operação, conectado a outros recursos capazes de inventar um modo diferencial de representação das chacinas escolares. A segunda parte apresenta um estudo analítico do conjunto de reportagens sobre o massacre de Realengo, publicadas na referida edição da revista Veja, destacando as explicações relativas à personalidade do assassino, que acabam por narrar - e, por meio de sua narrativa, inventar - aquela chacina por um viés psicologizante do eu assassino de quem a cometeu. A terceira e última parte destaca a diferença dos modos como Elefante e Veja inventam as respectivas chacinas de que tratam, apontando como Elefante inaugura uma rota de fuga que permite outras possibilidades de pensar sobre chacinas escolares, impossível de ser traçada por meio das representações contidas nas reportagens de Veja.

\section{A Invenção do Massacre de Columbine pelo Filme Elefante ${ }^{5}$}

O próprio nome do filme, originalmente Elephant ${ }^{6}$, já nos indica uma desterritorialização em relação a como Gus Van Sant escolheu tratar o massacre de Columbine. Na perspectiva da parábola hindu, o filme trabalha com a ideia de que a apreensão do que ocorreu naquela escola não pode ser feita total e definitivamente a partir da análise de suas partes.

Por meio da criação de paradoxos, Elefante conduz o espectador à indeterminação das causas, dos motivos e das razões da chacina. Mas o filme não opera apenas com a ideia de que os motivos são indeterminados; eles o são, além disso, também indetermináveis: por um lado, as causas não podem ser determinadas se analisadas sob apenas um ponto de vista (psicológico, moral, sociológico, econômico, cultural etc.), o 
que torna o massacre indeterminado; mas, por outro lado, a soma dos pontos de vista também não é capaz de apreender o ocorrido em sua totalidade, o que o torna indeterminável. Tal como na parábola: não basta juntar as partes do corpo do elefante para que os cegos cheguem ao que é aquele animal; somando a contribuição do cego $1+$ cego $2+$ cego $3+$ cego 4 + cego 5 + cego 6 ainda assim não se chega à figura do elefante. Daí que se conclui, na perspectiva da parábola utilizada pelo filme, a indeterminabilidade do real.

Portanto não se trata apenas de que o massacre é indefinido; ele é também indefinível. É inexplicável. Não há respostas seguras, certas, verdadeiras. Interessante são os jogos de cena propostos por Gus Van Sant que permitem que se subtraia do filme algumas prováveis causas da chacina, ao mesmo tempo em que, no desenvolvimento da narrativa, elas são reposicionadas como movediças, frágeis e paradoxais. Ou seja, há um jogo de paradoxos proposto pelo filme cujo principal efeito está na possibilidade de se desconstruir as explicações e compreensões instituídas, especialmente aquelas relativas à personalidade dos assassinos - tão comumente apresentadas como leitmotiv de chacinas escolares. Vejamos pelo menos dois modos de funcionamento desse jogo de paradoxos, que operam desconstruções potentes.

Uma das prováveis causas do massacre de Columbine que pode ser subtraída do filme é a debilidade da estrutura familiar, nos moldes da família nuclear moderna - segundo os quais os pais e as mães devem proteger seus filhos, por meio, por exemplo, da presença constante em suas vidas e da atenção e estabilidade a eles oferecidas. Em Elefante, as famílias dos dois autores da chacina são ocultadas. Os pais e as mães de Alex e Eric não têm nome nem imagem no filme, podendo-se supor disso a sua ausência na vida dos filhos. Daí a questão: este seria um dos motivos que levaram os dois garotos a cometer o crime?

Como contraexemplo, na contraefetuação da procura por causas sociofamiliares para o comportamento assassino de Alex e Eric, há o caso de John, cujo pai também não é atencioso, o que se depreende do conflito apresentado já na primeira cena do filme: o pai de John está bêbado e vem guiando o carro de modo desgovernado. É John quem cuida de seu pai, quem o protege, quem o aconselha, e quem, em seguida, sofre as pressões por tal feito, já que, ao chegar à escola, o adolescente é punido pelo atraso que isso lhe gerou. No entanto nada disso foi motivo para que ele se tornasse um assassino, apesar de John ser o personagem que, no filme, vive as maiores pressões no que se refere à falta do que comumente se entende por estruturação familiar. Tem-se, assim, a fragilidade desta possível causa, apesar de ela também poder ser considerada como provável.

Uma segunda ocorrência que é tomada usualmente como leitmotiv das chacinas e da violência escolar é a discriminação que alguns jovens sofrem na escola, ficando expostos a risadas e chacotas dos colegas, fenômeno atualmente conhecido como bullying. No filme, isso fica 
A Invenção de Chacinas Escolares

evidente na cena em que Alex (um dos autores da chacina) está na aula, ocupando um lugar no fundo da sala, quando um de seus colegas atira nele o que parece ser uma bola de papel higiênico molhado, que gruda em sua roupa e em seus cabelos. Isso é feito pelo colega de modo intencional e sorrateiro, sem deixar que o professor perceba, mas tornando o ato visível a vários alunos da sala e, assim, expondo Alex ao ridículo. A discriminação que Alex parece recorrentemente sofrer na escola e seu isolamento na aula podem compor os motivos do massacre?

Como contraexemplo, operando a desconstrução desta asserção, há a personagem Michelle, discriminada de modo ainda mais recorrente. É ela quem, no filme, incorpora a figura da grande excluída, da loser por excelência, retratada como aquela cujo corpo e modos de ser não se enquadram nos diagramas das relações estabelecidas em Columbine. Contudo isso não foi motivo para que Michelle se tornasse uma assassina, apesar de encarnar a figura de maior discriminação e isolamento da escola. Tem-se, de novo, a exibição e, a seguir, a desconstrução dessa possível causa, apesar de ela também poder ser considerada como provável.

Além dessas duas causas tipicamente adotadas para explicar e justificar as chacinas escolares - mas envolvidas no jogo de paradoxos recorrente em Elefante -, podem-se depreender do filme outros possíveis motivos, que ainda conservam o seu caráter fugidio, movediço, insatisfatório, inconclusivo. A explicação para o massacre estaria na facilidade de comprar armas nos Estados Unidos? Os jogos de computador que incitam o desejo, o gosto e a vontade de matar poderiam ser a justificativa para a matança em Columbine? Os motivos estariam no fato de que Alex e Eric assistiram pela televisão ao filme Arquitetura da Destruição $0^{7}$ o que os implicaria como fãs do neonazismo? Nada disso parece muito potente para explicar o horror do que ocorreu naquela escola, afinal: a compra de armas nos Estados Unidos não é uma facilidade exclusiva aos autores da chacina; os jogos de computador considerados como violentos são os preferidos de muitas crianças e adolescentes; o filme Arquitetura da Destruição é uma crítica potente à estética nazista, como modo de concepção e funcionamento do nacional-socialismo. É nesse jogo de paradoxos que os personagens de Elefante se movimentam, conduzindo o espectador à indeterminabilidade das causas do massacre.

Também outros paradoxos são propostos, agora não diretamente relativos às causas, mas que compõem as tramas do filme de modo a realçar o caráter ambivalente da tragédia de que trata. No que se refere a isso, pode-se destacar a cena na qual Alex aparece em seu quarto, ao piano. Enquanto ele toca o refinado clássico Sonata ao Luar de Beethoven, a câmera vai lentamente se deslocando e mostrando a composição daquele ambiente - que pouco se diferencia das características gerais do quarto de um garoto adolescente - até focalizar Eric, que, atirado na cama, está entretido com um violento jogo de computador, no qual o boneco principal dispara contra todos os que cruzam seu caminho, 
promovendo uma matança geral. $\mathrm{O}$ fato de que as duas coisas (a tranquilizadora música clássica e a aterrorizante matança do jogo) estão acontecendo ao mesmo tempo e naquele mesmo espaço tem o efeito de nos incomodar: elas não combinam, não se ajustam, não se harmonizam, excluem uma a outra, são conflitantes, ambíguas, opostas; e, no contexto de sua apresentação sincrônica, afirmam o efeito paradoxal de Elefante.

É assim que, por meio do jogo de paradoxos, vemos se afirmar ao longo de Elefante uma trajetória nonsense, sem explicações, que apela para a multiplicidade: esta parece ser a opção assumida por Gus Van Sant para afastar as causas deterministas, esperadas e consideradas certas e verdadeiras.

Há várias cenas que evidenciam o estilo nonsense de Elefante, que pode ser encontrado, por exemplo, nas passagens em que se focaliza um céu escuro e nebuloso, no qual nuvens passam, se formam e se dispersam. Cena três vezes repetida: 1) como cena inicial, em que se ouvem apenas os comandos: “comecem”, "para”, "vão”; 2) na noite anterior ao massacre, com Alex e Eric dormindo; 3) como cena final, quando se abre um céu azul, de nuvens esvoaçantes, tudo um tanto disperso e gasoso demais, sem formas, em perpétuo deslocamento. O que isso vem nos dizer? Novamente não se pode esperar do filme algum tipo de resposta ou conclusão, somos deixados à deriva: a inconclusão nos força a pensar.

No que se refere à aposta de Elefante na multiplicidade, é emblemática a cena que acontece no corredor da escola, quando Elias fotografa John, e Michelle passa por ali correndo. Cena também três vezes repetida, mas com três ênfases diferentes que desfocam a nossa memória e nos põem a ver o mesmo como se fosse pela primeira vez. Visão sempre renovada, deixando a sensação de que, para o mesmo corredor, com os mesmos personagens, pode ser sempre possível inventar uma cena diferente, um olhar diferente, uma vida manifesta que seja diferente. Foco no mesmo, sob perspectiva diferencial; diferença manifesta paradoxalmente sob o mesmo espaço-tempo.

Quanto à sincronia posta em ação por Elefante, é importante ressaltar a ruptura cronológica da narrativa fílmica que tem como efeito, para o espectador, a percepção da simultaneidade dos acontecimentos. Presente, passado e futuro aparecem entrelaçados e ocorrendo ao mesmo tempo, indicando que as histórias coexistem e se coimplicam. Essa forma de narrar possibilita que o espectador perceba a sobreposição de vidas, de olhares, de expectativas, de conversas, de angústias: a diversidade de veias pulsando num mesmo contexto, num mesmo espaço e às vezes numa mesma situação, retomados e reapresentados sob ângulos e perspectivas diferentes.

Todos esses recursos cinematográficos inventam uma contraefetuação das formas tradicionais e usuais de abordar o massacre que ocorreu em Columbine: em vez de apostar em causas psicológicas apresentadas por discursos de experts que perseguiriam a constituição das 
A Invenção de Chacinas Escolares

personalidades assassinas de Alex e Eric, Elefante escolhe um olhar diferencial que se efetiva por meio da microfísica dos controles e disciplinamentos em que os alunos de Columbine encontram-se enredados. Essa microfísica está associada a uma singularização dos acontecimentos que se passam com os alunos daquela escola. Portanto não se trata de experts falando da chacina. Ao contrário, o filme joga com uma cartografia $^{8}$ da vida daqueles jovens, do que é cotidianamente vivido, sem atribuir valores a possíveis culpados ou inocentes.

Entre os flagras dos microcontroles a que estão submetidos aqueles jovens de Columbine, um deles está no olhar que o diretor da escola lança sobre John, como reprovação por seu atraso. Cena congelada, que reaparece instantes depois para enfatizar a potência disciplinadora e punitiva daquele olhar. Outro flagra está na cena envolvendo Brittany, Jordan e Nicole no refeitório da escola, quando aparece o excessivo controle que uma faz sobre a outra em atos tão ordinários como comer ou organizar o tempo. As nuances de hipercontrole das garotas entre si e consigo mesmas contrastam com a vigilância ininterrupta que suas famílias exercem sobre elas, expressa na cena em que as três reclamam que as suas mães vasculham suas coisas, invadem suas privacidades em busca de algo que as garotas estão supostamente escondendo, sem ter, segundo elas, razões para isso.

Várias cenas do filme, mas especialmente as que flagram a referida microfísica, são muitos potentes por conterem em si diferentes formas de controle, entrecruzadas, esparsas e acumuladas, ascendentes e descendentes, de si e do outro, tudo ao mesmo tempo. São cenas que mostram a fragilidade da hipótese de que existem, situados em posições opostas, fixas e imutáveis, aqueles que controlam e aqueles que são controlados. O que essas cenas nos permitem ver é a sobreposição de controles diversos, dispersos, móveis, advindos de (simultaneamente exercidos e sofridos por) diferentes sujeitos, instituições, práticas, discursos, sejam eles morais, médicos, jurídicos, estéticos, pedagógicos. Controles que atravessam os sujeitos não apenas porque é sobre o corpo deles que se exercem, mas porque são os próprios sujeitos que os colocam em operação, que os fazem funcionar. São os próprios sujeitos que se controlam e se regulam mutuamente, por meio também do seu autocontrole, de sua autorregulação.

Quanto à singularização dos acontecimentos, Van Sant se vale de pelo menos dois recursos para efetivá-la - a lentidão e o silêncio -, utilizados como estratégias narrativas às vezes sobrepostas, com o efeito de mostrar o que é sutil e o que escapa, evidenciando o cotidiano, o corriqueiro, o ordinário, o que é breve e extemporâneo.

Para além da decupagem ${ }^{9}$ das cenas que apresentamos aqui, e junto com elas, o que se pode dizer de Elefante, de modo geral, é que, durante quase todo o filme, não há pistas que evidenciem que o massacre está prestes a ocorrer. Nada indica que "algo ruim vai acontecer" até que Alex pronuncie essa frase, praticamente no final do filme. Talvez a 
cena em que Alex aparece no refeitório pela primeira vez sirva como um indício: ele faz anotações numa caderneta; a menina quer saber o que é; "é o meu plano [...] você vai ver". Mesmo assim, essa passagem não é um aviso claro a ponto de antecipar a matança a que assistiremos nas cenas finais. Diante da normalidade da vida daquela escola, o máximo que se imagina é que o garoto cometerá alguma travessura sem maiores consequências. Perplexidade. Surpresa! Algo ruim aconteceu. Alguém fez. Foram Alex e Eric. A sensação é a de que qualquer adolescente daquele filme poderia ter feito, embora, até certo ponto, nada há além de vidas de jovens aparentemente normais. Contradição, confusão, espanto, assombro.

Chegado o momento de assistirmos à matança, ela nos força a desconstruir a suposta tranquilidade daquele lugar. Primeiro, há cenas sobre as vidas diárias dos jovens na escola. De repente, há cenas sobre dois jovens matando as pessoas da escola. Evento inesperado, repentino, não anunciado previamente. A imprevisibilidade do fato nos faz querer procurar as causas. Será a chacina o terrível efeito daquele cotidiano tão supostamente normal que o filme aborda desde seu início? Esperamos que o final do filme nos responda, mas as causas não são apresentadas em definitivo. Há apenas efeitos. O filme não anuncia a razão de ser da chacina, não localiza a origem do problema, não apresenta explicações sociológicas, psicológicas, filosóficas, religiosas, familiares ou de qualquer outro tipo para as atitudes de Alex e Eric. Não há julgamentos. Não há discussões moralizantes. E, ao mesmo tempo, tudo cheira à moral...

O princípio que faz com que algo se torne aquilo que é não está dado de uma vez por todas em Elefante. Mas as possibilidades estão lá, o tempo inteiro. E é exatamente isso que o torna tão potente, porque não há palavras para descrever o comportamento humano, embora grande parte do nosso desejo diante do horror caminhe nessa direção. As categorias explicativas que poderiam ser usadas no filme para descrever e entender as pessoas e suas práticas talvez não fossem suficientes para captar o caráter tão impactante e perturbador da atitude dos garotos. Diante da ineficiência das palavras, há o suposto silêncio delas. Há o (aparentemente fora de propósito, supostamente desnecessário e às vezes irritante) silêncio de cenas que demoram a se desenrolar, longos e vagarosos trajetos percorridos por alguns personagens. Grande parte do tempo embalado pelo som suave de músicas clássicas cuja melodia inspira paz e tranquilidade, Elefante fala mais - estrategicamente quando não há diálogos.

Enfim, não se trata de pareceres que alguns experts poderiam oferecer sobre o massacre abordado no filme. Não se trata de pessoas falando sobre a chacina. Quem fala sobre a chacina são as vidas ordinárias daqueles jovens, apresentadas num ambiente tão supostamente normal, e ao mesmo tempo tão cheias de pressão de todo tipo. Assim, o filme não conclui em definitivo os motivos pelos quais Alex e Eric fize-

Educação \& Realidade, Porto Alegre, v. 39, n. 1, p. 303-323, jan./mar. 2014. 311

Disponível em: <http://www.ufrgs.br/edu_realidade> 
ram "algo ruim [...] acontecer". E o fato de que algo ruim acontece faz o filme continuar para nós, mesmo depois que ele acaba: afinal, por quê? Evento fortuito? Há justificativas? Onde encontrá-las? Eis o desconforto do espectador: é ele quem vai ter que interpretar; e há uma série de interpretações possíveis, mas igualmente paradoxais e ambivalentes. $\mathrm{O}$ filme nos força a desconstruir e nos força a pensar.

O incômodo maior aparece quando se percebe que, na ausência das causas diretamente ligadas aos assassinos, qualquer um ali poderia assumir aquele papel: John teria feito aquilo? Elias? Michelle? Acadia? Brittany? Jordan? Nicole? É assim que, em Elefante, Alex e Eric são dessubjetivados de um eu ou de uma personalidade assassina, compartilhando com o coletivo dos personagens as condições de possibilidade para o massacre. Em plena imanência, recusando os usuais apelos ao sujeito e a um suposto $\mathrm{eu}$ assassino transcendental, Elefante dessubjetiva para desculpabilizar. Assim, libertos dos grilhões da culpabilização, recuperamos a força do desejo de pensar.

\title{
A Invenção do Massacre de Realengo pela Revista $V e j a^{10}$
}

Como vimos, Elefante trata especificamente de um episódio: o massacre que ocorreu em Columbine. Mas o que pretendemos interrogar agora é: o que ele pode nos fazer pensar acerca dos modos de invenção discursiva que permite narrar uma chacina escolar? Ou, mais especificamente: a partir do modo como a narrativa fílmica de Elefante foi inventada, o que ela pode nos fazer pensar sobre o massacre que ocorreu em Realengo?

Para tanto, procederemos a um breve estudo da matéria sobre o caso Realengo, publicada pela revista Veja, fazendo para as seis reportagens que a compõem a mesma pergunta que fizemos para Elefante: o que esta matéria dá a pensar? O que é possível ser pensado a partir dela? ${ }^{11}$

Para atravessar a leitura que queremos fazer das reportagens, selecionamos um parágrafo do livro Conversações, de Deleuze (1992, p. 55-56), que aqui nos serve como um disparador analítico:

\begin{abstract}
É improvável que a professora, quando explica uma operação ou ensina a ortografia na escola, esteja transmitindo informações. Ela manda, dá palavras de ordem. E fornece-se sintaxe às crianças assim como se dá ferramentas aos operários, a fim de que produzam enunciados conformes às significações dominantes. É bem literalmente que é preciso compreender a fórmula de Godard: as crianças são prisioneiros políticos. A linguagem é um sistema de comando, não um meio de informação.
\end{abstract}

Para o tratamento analítico que daremos às reportagens de Veja, queremos reter do parágrafo supracitado especialmente a ideia de que “[...] a linguagem é um sistema de comando, não um meio de informa- 
ção" e que quando educamos, quer seja pelo aprendizado de uma língua na escola, quer seja pela linguagem que consumimos dos meios de comunicação, não nos informamos, mas vamos nos tornando presos políticos das representações dominantes que são veiculadas.

Após conhecermos os modos diferenciais como Elefante é capaz de nos pôr a pensar sobre o massacre de Columbine, vejamos como, num sentido oposto, podemos ser presos políticos das representações que a revista Veja utiliza para narrar - e, portanto, inventar, numa determinada direção - o massacre de Realengo.

"Cruel, aterrador e inexplicável": eis o título da primeira reportagem. Logo abaixo, a frase que segue, como subtítulo, explica: "o massacre de doze crianças em uma escola do Rio foi urdido por uma mente doentia [...]". Percebe-se, assim, que as primeiras frases da matéria dão o tom geral do modo como a chacina de Realengo é tratada na Veja. Apesar de afirmar que o massacre é "inexplicável", o que a revista faz o tempo todo é operar com tentativas diversas de explicações, todas elas ligadas ao perfil $p s i$ do assassino e seu contexto e modo de vida.

A própria capa dessa edição de Veja já anuncia a solução para o caso: ocupando toda a página frontal, está estampado o rosto de Wellington Menezes de Oliveira, autor da chacina, e sobre a imagem a seguinte inscrição: "O monstro mora ao lado. Como saber quando a loucura assassina emergirá das camadas profundas de anos de humilhação, solidão e frustração?"

Com sua capa e as seis reportagens que compõem a matéria dessa edição especial, Veja desloca a ênfase dos assassinatos para o assassino, como se, subjetivando o massacre num eu ou numa personalidade privada e individual, pudéssemos explicar as causas e as razões do episódio. Assim, a partir de um duplo centramento - num eu assassino transcendental e no poder de decifração deste $e u$ pelas ciências $p s i-o$ traçado do perfil $p s i$ do assassino passa a ser a senha que decifra todos os códigos de compreensão do massacre; passa a ser o segredo que desvenda o mistério e traz à luz as evidências da tragédia, antes ocultadas pelo invólucro que abrigava a personalidade assassina de Wellington, entendida como estando presente nele desde sempre. Portanto o retrato psi e moral de Wellington passa a ser a chave que abre todas as portas para a compreensão dos motivos que fizeram o massacre de Realengo acontecer.

Ainda que longos, vejamos alguns trechos das reportagens (Veja, 2011, p. 83-85):

A faceta monstruosa de Wellington Menezes de Oliveira, 23 anos, começou a revelar-se às $8 \mathrm{~h} 11$ de quinta-feira, quando ele entrou em uma sala de aula, sorriu e avisou aos estudantes: "Vim dar uma palestra". [...] Outras estranhas facetas desse rapaz adotado com dias de vida por parentes da mãe esquizofrênica já tinham vindo à tona antes. Na escola [...] ele era o "esquisitão da turma" [...]. 
A Invenção de Chacinas Escolares

Em casa, vivia pendurado na barra da saia da mãe, testemunha de Jeová, e usava camisa e calça sociais mesmo nas poucas festas em que aparecia. Mas os traços mais evidentes de seu desequilíbrio mental surgiram há cerca de dois anos. Wellington, relatam parentes, começou a pesquisar obsessivamente sobre armas e organizações terroristas islâmicas na internet. Passou a usar só roupas pretas e deixou crescer a barba.

[Transformou] em palco da sua carnificina o colégio em que havia estudado - e do qual não guardava boas recordações. Aluno mediano [...], ele não tinha amigos e era alvo de piadas e humilhações da classe. Aos 10 anos, foi lançado a uma lixeira pelos colegas. Era apelidado de Sherman, uma referência ao personagem nerd do filme American Pie. "A gente o xingava de tudo, zoava até cansar", diz um ex-colega. Suspeita-se de que ele selecionou suas vítimas pelo sexo. Dez das crianças mortas eram meninas [...]. Wellington [...] nunca teve um envolvimento amoroso com quem quer que fosse. "Acho realmente que era virgem", diz um vizinho.

Uma mente perturbada: sem amigos nem confidentes conhecidos, vivendo longe da família, Wellington deixou pouquíssimas pistas sobre os motivos que o levaram a matar.

Criança-problema: o boletim de Wellington revela que, aos 8 anos, ele já demonstrava os problemas de relacionamento que carregaria por toda a vida: dificuldades de expressão e distância da realidade.

[Observações da professora de Wellington, contidas no boletim escolar do $2^{\circ}$ bimestre do ano letivo de 1996]: É um aluno que caminha muito devagar, está em processo, precisando de ajuda direta do professor ou dos colegas de seu grupo, para realizar no máximo $39 \%$ do trabalho escolar. Na maioria das vezes parece estar bem distante da sala de aula. É um aluno que precisa de mais tempo para assimilar os conteúdos.

Como se pode perceber dos trechos citados, os enunciados de Veja sobre a chacina são enviesados por um repertório e por uma adjetivação psi da personalidade de Wellington, descrita nas reportagens pelas seguintes expressões: "loucura assassina”, "mente doentia”, "desequilíbrio mental”, "mente perturbada”, “criança-problema”, "problemas de relacionamento", "dificuldades de expressão", "distância da realidade". São expressões lacônicas, que tendem para uma vulgata do saber das ciências $p s i$.

De fato, a recorrência dessas representações nas reportagens, repetindo-as constantemente, reafirmando suas ideias em cada comentário e argumento apresentados, permite constituir o massacre como um traço privado e individual de quem o cometeu: passa-se recorrente- 
mente do crime ao comportamento do criminoso, de modo que o comportamento do criminoso passa a ser o próprio crime. Não se explica o massacre (porque, afinal, ele é inexplicável). Diante da inexplicabilidade do massacre, diante da indeterminabilidade do real, a revista Veja propõe palavras de ordem que decifram e explicam o sujeito, transformando-o no próprio motivo da chacina.

Isso faz surgir, sobreposto à chacina, o "[...] seu duplo, que com ela se parece como um irmão ou uma irmã" (Foucault, 2001, p. 21) e que desloca o foco dela, fazendo-a aparecer como uma "[...] irregularidade em relação a certo número de regras que podem ser fisiológicas, psicológicas, morais etc." (Foucault, 2001, p. 21). Portanto, diante da impossibilidade de explicar o massacre, o que as reportagens da revista fazem é criar o seu "duplo psicológico e moral"12, já que sobre esse é possível fazer todas as conjecturas necessárias para apresentar explicações que encerram o caso. O que aparece é a irregularidade não do massacre, mas de quem o cometeu: o que é irregular é a natureza do assassino, que não corresponde à natureza humana, já que ele é descrito como tendo uma "faceta monstruosa".

Desse modo, não se trata do crime como uma irregularidade do contrato social, nem mesmo do crime como uma doença do corpo social: a patologia é colocada no criminoso, na perversidade de seu interior, no desequilíbrio de sua mente, na perturbação de sua alma, na monstruosidade de sua natureza; e é em direção ao $e u$ interior de Wellington que se voltam todas as explicações atribuídas ao massacre. Ainda que se fale do entorno da chacina, a ênfase recai sobre a inteligibilidade do $e u$ assassino de Wellington, evidenciando-se em detalhes seus comportamentos desde a infância, para des-cobrir, des-vendar, fazer aparecer as doses de monstruosidade que existem por trás de cada ínfima atitude dele ao longo de sua vida. A ideia é que o próprio Wellington, por ser monstro (não humano) - por provavelmente ter nascido monstro - pode conter em si mesmo as explicações de todos os desvios que podem derivar dele, ainda que, paradoxalmente, também por ser monstro, seja em si mesmo ininteligível.

Retomando o trecho supracitado, pode-se ainda perceber que o repertório psi de que Veja se vale vem enviesado por dois registros biográficos que, justapondo-se e imiscuindo-se às representações $p s i$, entram no processo de criminalização do assassino. Trata-se de dois registros concorrentes e complementares no papel que cumprem de circunscrever as irregularidades internas, biológicas, psicológicas e morais de Wellington Menezes de Oliveira. São eles, basicamente: 1) os antecedentes familiares e religiosos; 2) os antecedentes pedagógicos e escolares.

A reconstrução da biografia familiar e religiosa remonta ora à dissecção das possíveis irregularidades da relação mãe-filho para encontrar aí os traços da degeneração do caráter do assassino, ora apela para uma religiosidade usualmente tida como estranha e perigosa - em 
ambos os casos, carregadas de estereótipos e preconceitos. Apesar de imprecisas, conflitantes e confusas, temos as seguintes referências: "filho adotado", "vivia pendurado na barra da saia da mãe”, "uma mãe esquizofrênica”, "uma mãe testemunha de Jeová", "muçulmano” e "leitor do Alcorão".

Antecedentes pedagógicos e escolares também vêm à baila para dissecar a personalidade do assassino, em duas direções diferentes. Em primeiro lugar, recuperando as informações do seu boletim escolar de 1996, ressalta-se o déficit cognitivo de Wellington aos oito anos de idade, assinalando-se os seus problemas de aprendizagem: "aluno mediano", "aluno que caminha muito devagar", "aluno que precisa de mais tempo para assimilar os conteúdos”, “[...] aluno que precisa de ajuda diretamente do professor ou dos colegas para realizar no máximo $39 \%$ do trabalho escolar". Persistindo nesse viés psicologizante, em segundo lugar, deslocam-se os antecedentes do âmbito cognitivo para os relacionais - ligados ao que, na linguagem pedagógica mais recente, se denomina de saber conviver e saber $\operatorname{ser}^{13}$-, aparecendo referências ao bullying, às discriminações e às violências sofridas por Wellington na escola: "esquisitão da turma", "ele não tinha amigos e era alvo de piadas e humilhações da classe", "aos 10 anos, foi lançado a uma lixeira pelos colegas", "[...] era apelidado de Sherman, uma referência ao personagem nerd do filme American Pie”, “[...] a gente o xingava de tudo, zoava até cansar".

Curioso é o deslizamento dessa biografia relacional de Wellington do âmbito da socialidade escolar para o da sua sexualidade, endossada por duas expressões que aparecem ao longo do texto: "sexualmente frustrado" e "virgem". Ressalve-se aqui a tácita menção a uma homossexualidade enrustida, frequentemente encontrada na anormalização dos criminosos pelas ciências psi. É assim que o fato de as vítimas do massacre de Realengo serem em sua maioria meninas foi descrito pelos articulistas da revista como "ódio ao sexo oposto" e explicado pela suposta virgindade de Wellington, que "[...] nunca teve um envolvimento amoroso com quem quer que fosse".

Essa insistência nos antecedentes biográficos de Wellington enviesados de todos os lados pela interpretação psi é coerente com o tratamento dado por Veja às chacinas escolares de modo geral. Frisemos que o conjunto de reportagens também apontou aspectos comuns dos autores de 22 chacinas escolares, na tentativa de traçar um perfil dos assassinos:

Os autores de chacinas em escolas têm perfis diferentes, mas partilham de um mesmo sentimento, manifestado em doses brutais - a raiva de si próprios e do mundo. [...] Odiavam suas vidas. Estavam desesperados e deprimidos a ponto de desejar a própria morte. [...] 'O que faz de um jovem um assassino em massa é uma complexa combinação de fatores como ambiente, predisposição genética e 
características individuais' [...] têm histórico de depressão, sede de vingança e tendência suicida. [...] têm dificuldades em lidar com perdas e frustrações, e relatavam ter sofrido perseguições (Veja, 2011, p. 94-95).

A aposta de Veja em traçar um perfil criminalístico fundado na análise psi dos autores das chacinas escolares - descrevendo-os como "psicopatas", “desajustados", "deprimidos", "homicidas”, “suicidas", "mentalmente desequilibrados”, com "dificuldades de lidar com perdas e frustrações", "com baixa autoestima", "cheios de frustrações sociais e sexuais”, com "raiva de si próprios e do mundo" - dá ênfase novamente à ideia de que a personalidade assassina precede o crime, é anterior ao crime.

Transcendentalizando-se as causas e os motivos das chacinas escolares nos transtornos psi dos seus autores, subentende-se que a chacina de Realengo existia antes de ela acontecer: a chacina de Realengo é o próprio Wellington. Ou melhor: é o resultado das várias irregularidades psi-individuais, genéticas e ambientais, tal como sugerem os trechos citados - que Wellington passou a representar, com toda a profusão de determinantes psi, utilitariamente empregados de modo taxativo, embaralhado e confuso, mas que praticamente encerram o caso. Como resultado final, forjado pelo saber-poder $p s i$, Wellington $=$ monstruosidade.

Mas há uma sutileza irrevogável desse tipo de análise que Veja faz circular: ainda que Wellington seja esquecido, as representações $p s i$ dele criadas pela revista, na intenção de criminalizar sua personalidade monstruosa e, assim, encerrar o caso, serão cristalizadas, naturalizadas e eternizadas em nossos modos de pensar e agir. Ou seja: enquanto o caso estiver em voga, o motivo do massacre será o eu assassino de Wellington, mas assim que o massacre e Wellington forem esquecidos, permanecerá para nós a figura monstruosa que ele passou a representar: que é solitária, esquisita, desequilibrada, perturbada, obsessiva, raivosa, vingativa, que renega as leis da moral, que não gosta da vida que leva, que não gosta do mundo como ele é, e que, por tudo isso, é capaz de cometer uma chacina como aquela. O massacre de Realengo poderá ser esquecido, mas o duplo psi-criminalístico que Veja fez aparecer na análise desse massacre permanecerá em nossos modos de pensar e agir como a irregularidade que precisa ser reconhecida e combatida, em nós e por nós em relação a todos os que conhecemos.

Exemplo disso é que - ao constituir a chacina como um traço, ao mesmo tempo, psicopatológico e biográfico do assassino - a matéria se desenrola de modo a ir envolvendo o leitor no discurso do risco e do medo que reforça e é reforçado pelo discurso da necessidade de vigilância, regulação e controle de todos e de cada um. Se a psicopatia assassina dá sinais e indícios, então, o melhor remédio para evitar os episódios de chacinas escolares é a atenção contínua, detalhada e permanente de tudo e de todos ao menor traço de desregramento psi, aos antecedentes 
biográficos e aos modos de vida considerados anômalos. É o efeito perverso a que nos incitam os fragmentos que citamos abaixo:

Se entender a mente e as razões dos jovens assassinos é difícil, perceber que um massacre está prestes a acontecer é teoricamente mais fácil. Pouco antes de atacar a maioria dos assassinos envia sinais diretos e indiretos de que haverá uma chacina. [...] Indícios da tragédia sempre pairam no ar (Veja, 2011, p. 94-95).

"Tiroteios em escolas em geral ocorrem em sequência, com pequeno intervalo entre eles, influenciados por eventos anteriores" [...]. No dia seguinte ao massacre em Realengo, as redes sociais brasileiras estavam cheias de comentários assustadores e enaltecimentos a Wellington. "Se Deus existe, ele estará do seu lado, irmão, viva a minoria”, dizia um comentário no Orkut, na sexta-feira passada. "olhem pelo lado dele, ele tinha problemas pessoais e sociais, era uma pessoa fraca que se deixou abater pelo prazer da vingança", lia-se no YouTube. "Pior é que eu sei o que se passava na cabeça dele", escreveu um integrante do Twitter. Comentários frios e aterradores como esses, enaltecendo o assassino, são justamente os sinais [...] (Veja, 2011, p. 98).

Considerando os elementos em comum com chacinas ocorridas em outros países, é de temer que Realengo tenha posto o Brasil no circuito do terror escolar. O fator viral desse tipo de crime ao menos contém uma esperança: como costuma ser precedido de sinais e pistas na internet, familiares, amigos e colegas talvez possam identificá-los a tempo para evitar mais um massacre de inocentes (Veja, 2011, p. 100).

Como se vê, a ideia é a de que, a partir do caso Realengo, devemos temer o assassino, apesar de ele estar morto. Tememos as representações que dele foram construídas, ao redor do $e u$ assassino que ele passou a encarnar a partir das reportagens. E se é verdade que indícios e sinais deste $e u$ assassino estão no modo como Wellington levava sua vida, na sua biografia e nas suas irregularidades antes do próprio crime, então é preciso manter-se vigilante e em alerta. E é isso que tememos agora: as ínfimas irregularidades de quem quer que seja e que poderão levar esse quem quer que seja a cometer uma chacina.

A sensação geral que fica dos trechos citados, especialmente esses últimos, é a de que quanto mais minuciosos forem a vigilância e o controle, maior sua eficácia preventiva para evitar a barbárie. E esse controle, de acordo com a revista, poderá (e deverá) ser operado por nós, que agora - já capturados pela lógica discursiva das reportagens - estamos demasiadamente assustados com a possibilidade de que o terror escolar esteja mais perto do que imaginamos. Do final da matéria, novamente ao seu início, na capa: "O monstro mora ao lado". 
Capturados pelas representações psi que anormalizam e criminalizam o eu assassino de Wellington pela chacina de Realengo, resta a nós lamentar que seres assim existam, ter receio de que eles se aproximem de nós ou de quem gostamos, e torcer para que isso não aconteça. Resta-nos, ademais, sermos constante e minuciosamente atentos às crianças e aos jovens que nos rodeiam, especialmente os que nos são mais queridos, sempre em busca de identificar neles os mais indeléveis sinais, pistas e indícios de possíveis comportamentos estranhos que possam apresentar: em nome de uma normalidade psicológica, biológica, sexual, moral, pedagógica, familiar, religiosa etc.

\section{O Filme Elefante como Resistência: do sistema de comando às rotas de fuga}

As cenas de Elefante que selecionamos e apresentamos na primeira parte deste texto nos ajudam a evidenciar que, a partir da invenção de um modo de representação da chacina escolar que produz a indeterminabilidade de sua ocorrência, somos forçados a pensar. Como vimos, o filme propõe um jogo de paradoxos que opera, ao mesmo tempo, por meio da suposição e da desconstrução de possíveis causas da tragédia. Conectadas a esse jogo, estão algumas opções que Gus Van Sant faz para constituir a narrativa fílmica daquele acontecimento, de modo a afastar causas deterministas. Dentre as principais opções, estão: uma trajetória nonsense, na forma do absurdo, que apela para a multiplicidade; uma microfísica dos controles e disciplinamentos em que os alunos de Columbine se encontram enredados; e uma singularização dos acontecimentos que se passam com os alunos daquela escola, utilizando-se da lentidão e do silêncio como recursos cinematográficos.

Esse modo de narrar uma chacina escolar, inventado por Elefante, difere radicalmente do modo como a revista Veja inventou a sua narrativa sobre o massacre de Realengo, tal como evidenciamos na segunda parte deste texto. Na contramão do que faz Elefante, Veja é repleta de explicações sobre a chacina e suas possíveis causas, todas vinculadas a um suposto $e u$ assassino que pode ser segura e verdadeiramente revelado e decifrado pelos antecedentes psi e biográficos do autor do crime.

Mas o que queremos sublinhar dessas duas formas radicalmente diferentes de representar as chacinas escolares são os efeitos que cada uma delas tem sobre nós. No caso da narrativa que Veja criou sobre o massacre de Realengo, a gama de formulações explicativas contidas nas reportagens não nos leva a pensar fora dos enquadramentos psicopatológicos e biográficos apresentados, já que todas as palavras de ordem foram proferidas, para nos fazer produzir enunciados que estejam em conformidade com essas representações dominantes.

Não significa que as reportagens não nos levam a pensar nada. Significa que as reportagens não nos levam a pensar nada fora dos en-

Educação \& Realidade, Porto Alegre, v. 39, n. 1, p. 303-323, jan./mar. 2014.

Disponível em: <http://www.ufrgs.br/edu_realidade> 
A Invenção de Chacinas Escolares

quadramentos apresentados. A construção do discurso do risco e do medo coimplicado na defesa da (auto)vigilância, (auto)regulação e (auto)controle é exemplar nesse sentido. Isso quer dizer que passamos a pensar no interior desses discursos, e os tornamos ainda mais potentes quando os fazemos funcionar por meio dos enunciados que produzimos segundo sua lógica; acontece que os enunciados que proferimos a partir das reportagens não são mais do que reflexos das representações que consumimos da revista. A consequência lógica disso é que ficamos aprisionados pelos esquemas de inteligibilidade propostos por Veja. É justamente neste sentido que devemos compreender o que diz Deleuze (1999, p. 5) na conferência O ato de criação: "a informação é exatamente o sistema de controle", porque "informar é fazer circular uma palavra de ordem".

Diferentemente desse modo usual e dominante, a invenção proposta em Elefante é construída tendo como base o caráter ambivalente e paradoxal do massacre de Columbine. O fato de Elefante não eliminar as características ambivalentes do massacre de Columbine reduz a arbitrariedade de sua narrativa. Mas isso não significa que ela esteja imune às relações de poder: significa apenas que a narrativa nos oferece possibilidades de liberdade no interior das próprias relações de poder que inevitavelmente atravessam qualquer formação discursiva.

Nesse sentido, pode-se dizer que Elefante inventou rotas de fuga. E fugir das significações usuais atribuídas à chacina não significa correr para bem longe delas e evitá-las ou então negá-las e abandoná-las de uma vez por todas, livrando-se por completo delas. Fugir, nesse caso, significa encontrar um modo de fazer com que as significações fujam de si mesmas: que consigam se apresentar em sua mobilidade, multiplicidade, transitoriedade, ambiguidade e contradição, escapando de uma representação dominante e definitiva (que teria o efeito de fixá-las e asfixiá-las).

Por tudo isso, Elefante é um exemplo emblemático da função de resistência e libertação que o cinema (e a arte de forma geral) pode desempenhar. Afirma-se, assim, um uso inaudito do cinema no campo da educação: não mais como recurso didático-pedagógico para o ensinoaprendizagem, mas como máquina de guerra capaz de implodir as representações dominantes que estão inalienavelmente vinculadas às informações que consumimos. Eis, assim, as rotas de fuga que Elefante nos possibilita à prisão política em que Veja nos encerra.

Recebido em 25 de setembro de 2012 Aprovado em 27 de maio de 2013

\section{Notas}

1 Elefante tem como tema a chacina escolar que ficou conhecida como massacre de Columbine, que ocorreu em 20 de abril de 1999, no Instituto Columbine Littleton, Colorado, Estados Unidos. 
2 Trata-se de dois projetos de pesquisa (Contemporaneidade e Educação e Cinema e Educação: o que pode o cinema?), conectados a dois projetos de extensão (Cinema, Pensamento e Educação: uma perspectiva deleuziana e Cinema educação: um olhar pós-estruturalista), desenvolvidos junto ao Centro de Educação da Universidade Federal do Rio Grande do Norte, sob nossa coordenação.

3 Segundo Michael Peters (2000), o pós-estruturalismo reativa algumas teses do estruturalismo - como a crítica ao sujeito universal-, mas se diferencia dele por cinco inovações: 1) interesse por uma história crítica ao se concentrar na análise diacrônica da história, em sua mutação, na transformação e na descontinuidade das estruturas, que culminam na substituição da ontologia pela genealogia;2) questionamento do cientificismo pretendido pelo estruturalismo, adotando um perspectivismo nas interpretações, que desconstrói as estruturas universais; 3) crítica à noção de verdade, com ênfase na análise das relações de poder que sustentam uma política de verdade; 4) valorização da escrita e do estilo filosófico-crítico como potência analítica: os aforismos de Nietzsche, o ensaio em Foucault, o texto delirante de Deleuze; 5) ênfase no presente, na atualidade, no nós hoje como focos de problematização, cujo diagnóstico e desconstrução tática têm por objetivo a invenção de fraturas e linhas de fuga.

4 Quanto a possíveis objeções com relação à utilização de dois materiais empíricos distintos entre si, estamos concluindo a ampliação deste estudo, fazendo as mesmas questões acerca das representações de chacinas escolares, mas agora entre dois materiais cinematográficos: Elefante (Gus Van Sant, EUA, 2003) e Tiros em Columbine (Michael Moore, EUA, 2002). Resultados preliminares da ampliação deste estudo mostram que, apesar de se tratarem de materiais da mesma natureza (cinema) e apesar de os dois filmes tratarem da mesma chacina escolar (em Columbine), as representações inventadas por cada filme são radicalmente diferentes entre si. Portanto não é a diferença da natureza do material empírico que produz a diferença das representações que cada um deles inventa.

5 Entre os temas da obra do cineasta e roteirista norte-americano Gus Van Sant (nascido em 1952), destaca-se uma abordagem do absurdo, presente já no primeiro filme independente que dirigiu, em 1985, intitulado Mala Noche. Com Elefante, Van Sant ganhou o prêmio de melhor diretor e a Palma de Ouro, no Festival de Cannes de 2003. Dos muitos filmes que dirigiu, destacam-se: Garotos de Programa (1991), Gênio Indomável (1997) e Milk - A Voz da Igualdade (2008).

60 título faz, provavelmente, referência a uma parábola hindu na qual seis cegos sábios - embora amigos, também rivais na demonstração de sua sabedoria tocam uma parte do corpo de um elefante, e cada um dos sábios tenta descrever o animal a partir da parte que tocou: a barriga, a tromba, as orelhas, a cauda, as presas, a pata. Em função da parcialidade de suas apreensões, nenhum dos sábios é capaz de perceber o elefante em sua totalidade, apesar de suas versões se pretenderem generalizantes. Diante da discussão instaurada entre os seis sábios que - cada um a seu modo e a partir de sua perspectiva - tentavam defender suas verdades, o sétimo sábio cego pede a uma criança que desenhe no chão a figura do elefante. Tateando os contornos do desenho, percebeu que todos os outros sábios estavam certos e errados ao mesmo tempo, e concluiu: "[...] é assim que os homens se comportam perante a verdade. Pegam apenas numa parte, pensam que é o todo, e continuam tolos!”.

7 Trata-se do documentário de Peter Cohen (Alemanha, 1989/92), um clássico para nos fazer pensar que o nacional-socialismo foi concebido e funcionava a

Educação \& Realidade, Porto Alegre, v. 39, n. 1, p. 303-323, jan./mar. 2014.

Disponível em: <http://www.ufrgs.br/edu_realidade> 
partir de uma estética nazista da perfeição e da beleza, da pureza e da limpeza, da arte e da arquitetura, da saúde e da genética etc.

8 Estamos nos referindo à acepção que Deleuze e Guattari (1996) atribuem à expressão cartografia: uma espécie de sensibilidade investigativa adaptável e mutante que flagra as relações de forças - sempre imanentes, instáveis, dinâmicas e múltiplas - que compõem um campo específico de experiências. No contexto deste trabalho, entendemos que cartografar significa traçar as linhas que configuram uma espécie de diagrama de possibilidades, de fluxos e de devires que estão em jogo nos acontecimentos singulares vividos pelas personagens do filme.

9 O termo decupagem (do francês découpage, derivado do verbo découper, que, em português, significa recortar) nos parece apropriado para designar a atividade de ordenação e registro por escrito dos diversos planos que compõem as cenas que selecionamos do filme, conforme nossa percepção, enviesada pelas lentes analíticas que utilizamos aqui. Nesse sentido, não se trata propriamente de um processo de transcrição das cenas, que carregaria o sentido de fidedignidade ao original, mas da produção de um simulacro, uma vez que o processo de escritura não só recorta as cenas, como também é atravessado por um desejo interesseiro e interessado em recriá-las para enfrentar as problemáticas que se encontram sob investigação neste trabalho.

10 Quanto à inserção no contexto das revistas informativas de circulação nacional, de acordo com o Instituto Verificador de Circulação (IVC), Veja ocupa o topo na tabela de circulação média por edição, seguida pelas revistas Época e Isto É. Sua tiragem atual é de 1.207.579, sendo 929.865 assinaturas. Veja, que há 44 anos é uma publicação da Editora Abril, de periodicidade semanal, teve a sua primeira edição em 11 de setembro de 1968. Atualmente, além da revista Veja nacional, a Editora Abril também publica os suplementos Veja São Paulo e Veja Rio, com periodicidade semanal, além de eventualmente publicar suplementos para outras regiões, com dicas de turismo, gastronomia e outros. $\mathrm{O}$ site de publicidade da Editora Abril - <http://publicidade.abril.com.br $>$. Acesso em: 5 fev. 2013 - informa alguns dados quanto ao perfil atual dos leitores de Veja: $43 \%$ são do sexo masculino e $57 \%$ do sexo feminino; $41 \%$ têm entre 25 e 44 anos de idade; $20 \%$ são da classe A, 53\% da classe B e $24 \%$ da classe C; $58 \%$ são do Sudeste, $14 \%$ do Sul e $14 \%$ do Nordeste.

11 Trata-se da matéria especial de Veja (2011) anunciada na capa sob o título "Massacre de Realengo". Essa matéria é composta por seis reportagens, assim intituladas: "Cruel, aterrador e inexplicável”; "Vidas abreviadas"; "Só o dever cumprido"; "Vidas a ser reconstruídas"; "O que estes assassinos têm em comum"; "O efeito viral das matanças".

12 Expressão criada por Foucault (2001) ao estudar exames psiquiátricos utilizados em práticas judiciárias.

13 Dois dos quatro pilares da educação propostos no Relatório para a Unesco da Comissão Internacional sobre Educação para o século XXI (Delors, 1998).

\section{Referências}

DELEUZE, Gilles. A Imagem-Tempo. São Paulo: Brasiliense, 1990.

DELEUZE, Gilles. Conversações. Rio de Janeiro: Editora 34, 1992. 
DELEUZE, Gilles. O Ato de Criação. Folha de São Paulo, Caderno Mais! São Paulo, p. 4-5, 27 jun. 1999. Disponível em: <http://www.makidea.com.br/2010/06/03/ ato-de-criacao >. Acesso em: 9 jun. 2012.

DELEUZE, Gilles; PARNET, Claire. Uma Conversa: que é, para que serve? In: DELEUZE, Gilles; PARNET, Claire. Diálogos. São Paulo: Escuta, 1998. P. 9-47.

DELEUZE, Gilles; GUATTARI, Félix. Mil Platôs: capitalismo e esquizofrenia, v. 3. São Paulo: Editora 34, 1996.

DELORS, Jacques (Org.). Educação: um tesouro a descobrir. Relatório para a Unesco da Comissão Internacional sobre Educação para o século XXI. São Paulo: Cortez; Brasília: MEC/Unesco, 1998.

ELEFANTE. Direção: Gus Van Sant. Produção: Diane Keaton. Intérpretes: Alex Frost, Eric Deulen, John Robinson e outros. Roteiro: Gus Van Sant. EUA, 2003. 1 DVD (81 min.).

FOUCAULT, Michel. Os Anormais. São Paulo: Martins Fontes, 2001.

FOUCAULT, Michel. A Verdade e as Formas Jurídicas. Rio de Janeiro: Nau, 2005. PETERS, Michael. Estruturalismo, Pós-Estruturalismo e Pós-Modernismo. In: PETERS, Michael. Pós-Estruturalismo e Filosofia da Diferença: uma introdução. Belo Horizonte: Autêntica, 2000. P. 9-44.

VEJA. São Paulo: Editora Abril, ed. 2212, n. 15, 13 abr. 2011.

Karyne Dias Coutinho é doutora em Educação pela Universidade Federal do Rio Grande do Sul (UFRGS), professora adjunta do Centro de Educação da Universidade Federal do Rio Grande do Norte (UFRN).

E-mail:kcout@terra.com.br

Alexander de Freitas é doutor em Educação pela Universidade de São Paulo (USP), professor adjunto do Centro de Educação da Universidade Federal do Rio Grande do Norte (UFRN).

E-mail:xander@usp.br 